\title{
Distribution of arsenic between the particulate and aqueous phases in surface water from three freshwater lakes in China
}

\author{
Fen Yang ${ }^{1,2,3} \cdot$ Di Geng ${ }^{1,2,4} \cdot$ Chaoyang $\mathrm{Wei}^{1,2} \cdot$ Hongbing $\mathrm{Ji}^{4} \cdot \mathrm{Hai} \mathrm{Xu}^{5}$
}

Received: 27 March 2015 / Accepted: 18 December 2015 / Published online: 26 December 2015

(C) Springer-Verlag Berlin Heidelberg 2015

\begin{abstract}
Total arsenic (As) in suspended particulate matter (SPM) of lacustrine ecosystems has been extensively documented, but knowledge on the distribution of As between the particle and aqueous phases in freshwater lakes remains largely unknown. The present study employed a rapid method to determine the total and dissolved As and As in SPM at sites covering the entire areas of three large shallow lakes in China, e.g., Taihu, Chaohu, and Dianchi, to obtain a "representative" mean value of the As concentration in various phases. The average concentrations of total and dissolved As were below 6.0 and $3.3 \mu \mathrm{g} / \mathrm{L}$, respectively. Arsenic in SPM was much higher than that in waters, as ranging from 24.7 to $516 \mu \mathrm{g} / \mathrm{g}$. Lake Taihu exhibited extensive seasonal variation both in total and dissolved As, while little difference was observed in SPM concentration, with an average value of 54.2 and $49.3 \mathrm{mg} / \mathrm{L}$ in winter and summer, respectively. Among the algae in the three lakes, Cyanophyta dominated in both cell abundance and biomass. Algae mass occupied significant parts of SPM, especially in Dianchi; the proportions of algae in the SPM fractions
\end{abstract}

Responsible editor: Céline Guéguen

Chaoyang Wei

weicy@igsnrr.ac.cn

1 Institute of Geographic Sciences and Natural Resources Research, Chinese Academy of Sciences, Beijing 100101, China

2 Key Laboratory of Land Surface Pattern and Simulation, Chinese Academy of Sciences, Beijing 100101, China

3 University of Chinese Academy of Sciences, Beijing 100049, China

4 Civil \& Environment Engineering School, University of Science and Technology Beijing, Beijing 100083, China

5 Nanjing Institute of Geography and Limnology, Nanjing 210008, China were measured as 10.4 and $7.1 \%$ in Taihu in winter and summer, $4.5 \%$ in Chaohu, and $53.3 \%$ in Dianchi, both in summer season. The total As in SPM had a significant positive relationship with total As in water and a high distribution coefficient (Kd) between SPM and dissolved fraction of As at all three lakes. The high proportions of Algae, especially Cyanophyta in the composition of SPM in the three large shallow lakes, might play an important role in affecting the As distribution between the aqueous and particulate phases in aquatic ecosystem.

Keywords Cyanophyta $\cdot$ Arsenic $\cdot$ Spatial variation · Suspended particulate matter

\section{Introduction}

Arsenic (As) is a ubiquitous and carcinogenic metalloid element found in soils, air, natural water, and living organisms (Mandal and Suzuki 2002). In recent years, a variety of sources, including mining, smelting, waste disposal, combustion of fossil fuels, use of arsenical pesticides and herbicides, and other human activities, have significantly elevated As in the environment (Smedley and Kinniburgh 2002). Shallow freshwater lakes are essential to the drinking water supply and are typically one of the major sinks for discharged As (Linge and Oldham 2002; Nikolaidis et al. 2004). In aquatic environments, As is distributed among the aqueous phase, suspended particulate matter (SPM) and sediments (Pertsemli and Voutsa 2007). SPM can play an important role in controlling the reactivity, transport, and biological impacts of As and other substances in the aquatic environment, and provides a crucial link for chemical constituents between the water column, bed sediments, and food chain (Kar et al. 2013). 
Arsenic distribution characteristics have been extensively documented in several freshwater lakes, in efforts to understand the migration and adsorption capacity of pollutants between the particle and aqueous phases and to evaluate the potential ecological risks to aquatic ecosystems (Huo and Chen 1997; Zheng et al. 2013). In natural waters, As can be rapidly adsorbed onto suspended solids from the aqueous phase, precipitated, and ultimately transported to sediments as a result of changes in physical, chemical, and biological factors. Factors influencing the allocation of As in freshwater lakes have been studied in recent years (Nguyen et al. 2005). Zheng et al. (2013) found that sediment resuspension had a remarkable impact on the release of contaminants, and SPM adsorption might be strengthened when hydrodynamic conditions became intensified. Geng et al. (2015) also reported the effects of wind-wave disturbance on the partitioning of As between the aqueous and suspended solids in the surface layer; they found that dissolved As increased, while the corresponding As in suspended solids decreased, with increasing wind speed.

Eutrophication promotes the multiplication of primary producers, like phytoplankton in lakes, which can significantly impact As circulation in aquatic systems (Hasegawa et al. 2009; Sohrin et al. 1997). Since $\mathrm{PO}_{4}$ and As(V) have similar chemical properties, phytoplankton might competitively intake $\mathrm{As}(\mathrm{V})$ in addition to phosphate (Hasegawa et al. 2010). Therefore, biological activities, such as growth, density, and reproduction of phytoplankton and other aquatic organisms, can likely influence variations in As occurrence (Rahman and Hasegawa 2012). The seasonal distribution of As in lakes has also been extensively documented in recent decades. Total As concentrations in summer being higher than those in winter were reported in several lakes. In these lakes, inorganic As was released to the bottom layer of the water column from sediments under anaerobic conditions in summer, whereas in winter, $\mathrm{As}(\mathrm{V})$ was adsorbed onto $\mathrm{Fe} / \mathrm{Mn}$ oxides and settled into sediments (Takamatsu et al. 1985; Barringer et al. 2007; Hasegawa 1997). In shallow and eutrophicated lakes, wind wave and constitutions in SPM may greatly affect the As occurrence and distribution between the water and SPM phases; however, these were still largely unknown up to now. This is partly due to that As in large shallow lakes are quite heterogeneous, the balance of adsorptiondesorption between the solid and water phases is difficult to obtain.

The objectives of the present study were (1) to determine the As concentration in the aqueous and SPM phases of surface waters in Lakes Taihu, Dianchi, and Chaohu, the three most polluted shallow freshwater lakes in China, and (2) to characterize the As distribution between the water and solid phases, and the impact of organic composition, mainly the algae mass, on the distribution characteristics.

\section{Materials and methods}

\section{Study area}

Lake Taihu is the largest lake in the eastern coastal region of China and the country's third largest freshwater lake (Zhang et al. 2014). It is located in the southern Jiangsu Province and the northern Zhejiang Province, covering an area of $2338 \mathrm{~km}^{2}$ with a mean depth of $1.9 \mathrm{~m}$ (Hu et al. 2010). It plays an important role in people's daily lives and industrial production in the region. It is also a repository for wastewater from urban centers and nearby agricultural and industrial segments with a rapidly growing local economy (Wang et al. 2013).

Lake Chaohu, located in the Anhui Province of East China, is the fourth largest freshwater lake in the country. It is a typical large, shallow, subtropical lake that covers an area of $780 \mathrm{~km}^{2}$ and has a mean water depth of $2.7 \mathrm{~m}$. Because of the agricultural intensification in recent decades, deterioration of the aquatic environment in the lake Chaohu Valley has become a serious environmental problem (Tang et al. 2010).

Lake Dianchi is the largest freshwater lake in Yunnan, with serious eutrophication since the 1990s. The lake body is approximately $40 \mathrm{~km}$ long and $12.5 \mathrm{~km}$ at its widest point, with an average water depth of $4.7 \mathrm{~m}$ and an area of $292 \mathrm{~km}^{2}$. With the development of agriculture, industry, and urbanization in the region, increasing sewage discharge has altered the freshwater biodiversity structure (Du et al. 2011).

Lakes Taihu, Chaohu, and Dianchi are the three most seriously polluted large shallow freshwater lakes in China and are also the three priority lakes selected by the Chinese government for water pollution control (Zhang et al. 2012).

\section{Sampling}

Surface water samples were collected at specific intervals from the above three lakes (Fig. 1). In June and December of 2013, 30 sites were sampled in Taihu, including 15 in Meiliang Bay (M1-M15) and 15 in Gonghu Bay (G1-G15). In July of 2013, 40 sites were sampled in Chaohu, including 20 in the eastern (C1-C20) and 20 in the western (C21-C40) areas of the lake. In September of 2013, 25 sites were sampled in Dianchi, including 8 sites in Caohai (D1-D8) and 17 sites in Waihai (D9-D25). At each sampling site, water quality parameters, including temperature (T), $\mathrm{pH}$, dissolved oxygen (DO), and chlorophyll-a (Chl-a), were measured using a multiparameter water quality analyzer (Aquaread AP-2000, UK; Table 1).

Water samples were taken with a water sampler $(2 \mathrm{~L}$ capacity) approximately $20 \mathrm{~cm}$ beneath the surface, and then transported in $500-\mathrm{mL}$ acid-washed polyethylene bottles. Three fractions were obtained for each surface water sample: (i) total, (ii) dissolved, and (iii) suspended particulate matter. After sample collection, approximately $400 \mathrm{~mL}$ of the water 

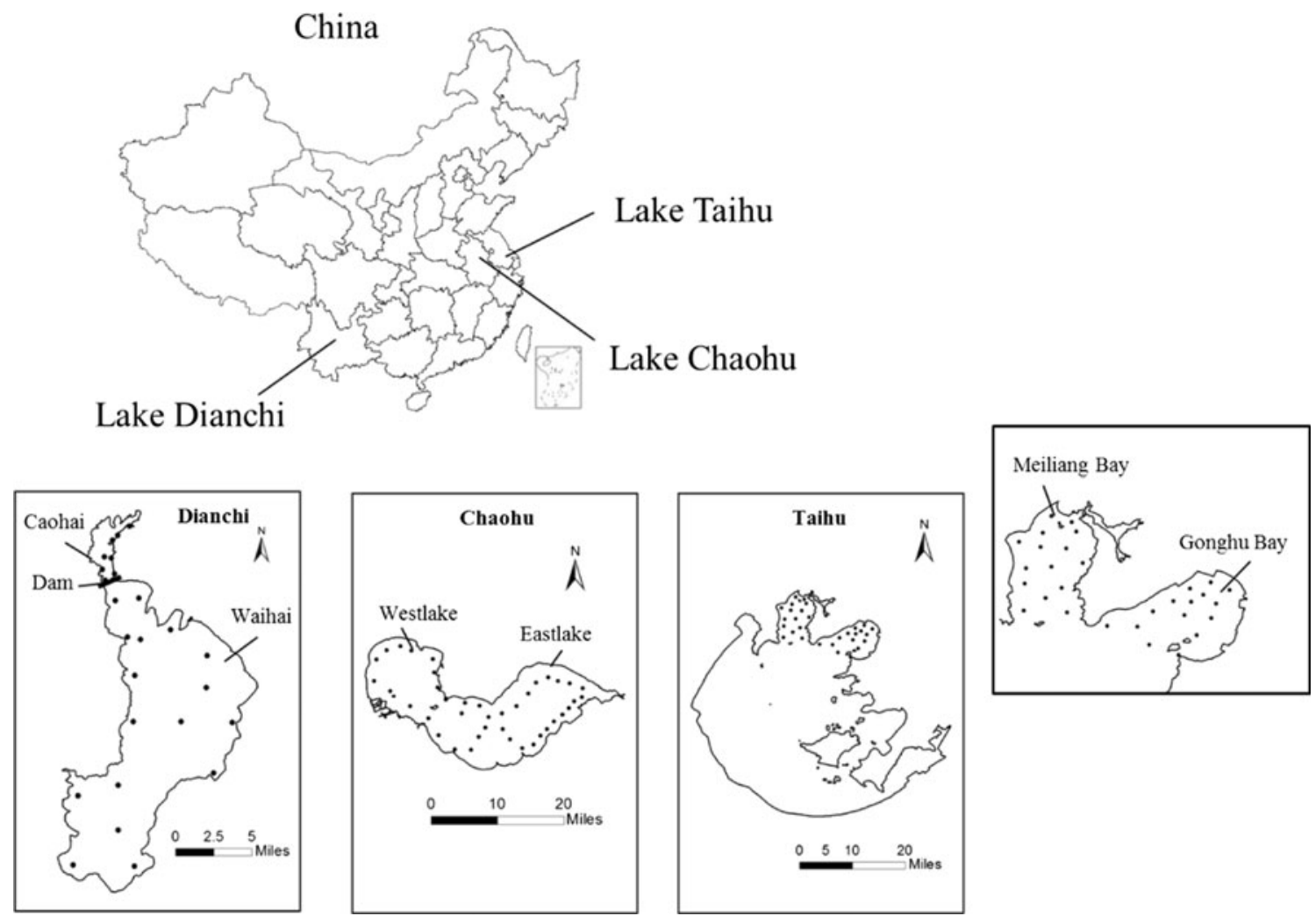

Fig. 1 The study area showing sampling locations in Lake Taihu, Chaohu, and Dianchi

sample were filtered immediately through dry pre-weighed $0.45-\mu \mathrm{m}$ cellulose acetate membrane filters (Beijing Beihua Sunrise Barrier Separation Technology Co., Ltd., China) by diaphragm vacuum pump filtration, which produced an air pressure of $5.3 \mathrm{~kg} / \mathrm{cm}^{3}$ to yield the dissolved and SPM fractions. The membranes were then dried in an oven $\left(105^{\circ} \mathrm{C}\right)$ to a constant weight and then re-weighed. The SPM concentration $(\mathrm{mg} / \mathrm{L})$ was estimated by the difference in weight between the filter with and without particles divided by volume of filtered water. For each $500-\mathrm{mL}$ water sample, 2-3 drops of concentrated nitric acid were added for As analysis while samples for $\mathrm{TN}$ and TP were preserved with $1 \mathrm{~mL}$ of a mixture of ultrapure $\mathrm{H}_{2} \mathrm{SO}_{4}$ and water $(1: 1, v / v)$. All samples were stored at low temperatures in the dark and transported back to the laboratory for analysis within 1 week.

\section{Analysis}

Reagents for acid digestion, including $70 \%$ nitric acid (metaloxide-semiconductor (MOS) grade, Beijing Institute of Chemical Reagents, Beijing, China), $71 \%$ perchloric acid $\left(\mathrm{HClO}_{4}\right.$, guaranteed reagent (GR) grade, Sinopharm Chemical Reagent Beijing Co., Ltd, Beijing, China), and deionized water $(18 \mathrm{M} \Omega \cdot \mathrm{cm})$ were used. For each sample, $20 \mathrm{~mL}$ of water was placed in a Teflon container with the addition of $8 \mathrm{~mL}$ of $\mathrm{HNO}_{3}$ and $1 \mathrm{~mL} \mathrm{HClO}_{4}$, and then heated at $180{ }^{\circ} \mathrm{C}$ on an electric hot plate until no white smoke arose. The digested solution was evaporated to near dryness and then cooled to room temperature. The solution was transferred to $25 \mathrm{~mL}$ with $5 \% \mathrm{HNO}_{3}$ in a graduated test tube, rinsing the digestion vessel several times with ultrapure water during transfer. After pretreatment, the As concentration in the digested solutions was analyzed on a hydride generation-atomic fluorescence spectrometer (HG-AFS; AFS-8230, Beijing Titan Instruments Co., Ltd., China). The detection limit of AFS for As was $0.01 \mu \mathrm{g} / \mathrm{L}$, and the analytical method precision (RSD) was within $10 \%$.

Total nitrogen (TN), total phosphate (TP), and the qualitative and quantitative phytoplankton determinations were performed at the Nanjing Institute of Geography and Limnology, Chinese Academy of Sciences. The TN and TP were measured using ultraviolet spectrophotometry (Ebina et al. 1983). For microscopic identification and quantification of phytoplankton, raw water samples $(1 \mathrm{~L})$ were placed into brown glass bottles and fixed immediately with $15 \mathrm{~mL}$ of Lugol's iodine solution in situ. Phytoplankton species was identified by using a stereoscopic microscope according to a handbook (Hu and Wei 2006). Algal biomass (mg/L) was calculated by the amount of single-cell organisms (mg/cell) multiplied by cell abundance (cells/L).

Arsenic has a volatile nature, and the quantity of SPM in lakes is typically not enough for further analyses and may lead to poor or erroneous results. More importantly, Geng et al. (2015) reported that the As blank in a cellulose acetate 
membrane could be as high as $1.6 \mu \mathrm{g} / \mathrm{g}$. To overcome these shortages, the As sorbed in SPM $(\mu \mathrm{g} / \mathrm{g})$ in the present study was indirectly calculated by incorporating the total (unfiltered raw water sample) and dissolved As contents (filtered water sample) and the SPM concentration (solid residue, $>0.45 \mu \mathrm{m}$ ) at each site, as presented in the following equation:

As sorbed in $\operatorname{SPM}(\mu \mathrm{g} / \mathrm{g})\left(\left(\mathrm{SPM}_{\mathrm{As}}\right)\right)$

$=[$ As in total $(\mu \mathrm{g} / \mathrm{L})-$ As in $\operatorname{dissolved}(\mu \mathrm{g} / \mathrm{L})] / \operatorname{SPM}(\mathrm{g} / \mathrm{L})$

\section{Quality assurance and control}

All glassware tubes were soaked in $10 \% \mathrm{HNO}_{3}$ at least $40 \mathrm{~h}$, washed, and rinsed at three times with deionized water before use. All reagents used during the analytical procedure were of analytical grade or higher. For each digestion batch, standard reference material, $16 \%$ replicates, and 2 analytical blanks were used as the quality assurance and quality control (QA) QC) procedure of the analysis. Reference of simulated natural water (GBW(E)080390) was used to verify the accuracy of the analytical method. The recoveries for As ranged from 89.1 to $113.3 \%$, with a mean value of $101.8 \%$.

\section{Statistical and spatial analyses}

Statistical analyses were carried out using SPSS v.11.5 (SPSS Inc., Chicago, USA). Correlations were evaluated using the bi-variation method to test the inter-relationship among the different parameters in the water samples from each site. To analyze spatial variability, interpolation mapping was performed using inverse distance weighted method in ArcGIS 9.30 (Environmental Systems Research Institute Inc., Redlands, CA, USA).

\section{Results}

\section{General water characteristics}

Superficial waters from the three lakes were slightly alkaline at all sampling sites (Table 1). In Taihu, samples analyzed in winter had a mean $\mathrm{pH}$ of 8.3 (ranged from 7.9 to 8.5), and in summer, the $\mathrm{pH}$ was between 8.3 and 9.4. The average $\mathrm{pH}$ values in lakes Chaohu and Dianchi were 8.4 and 9.2, respectively. The water temperature in Taihu exhibited strong seasonal variations, from $5{ }^{\circ} \mathrm{C}$ in December (winter) to $25^{\circ} \mathrm{C}$ in June (summer). In Chaohu, the temperature was $28^{\circ} \mathrm{C}$ in July and $23{ }^{\circ} \mathrm{C}$ in Dianchi in September. Moderate mean dissolved oxygen concentrations ranged from 97 to $111 \%$ in the three lakes and were at a maximum value (152\%) in Dianchi. In 


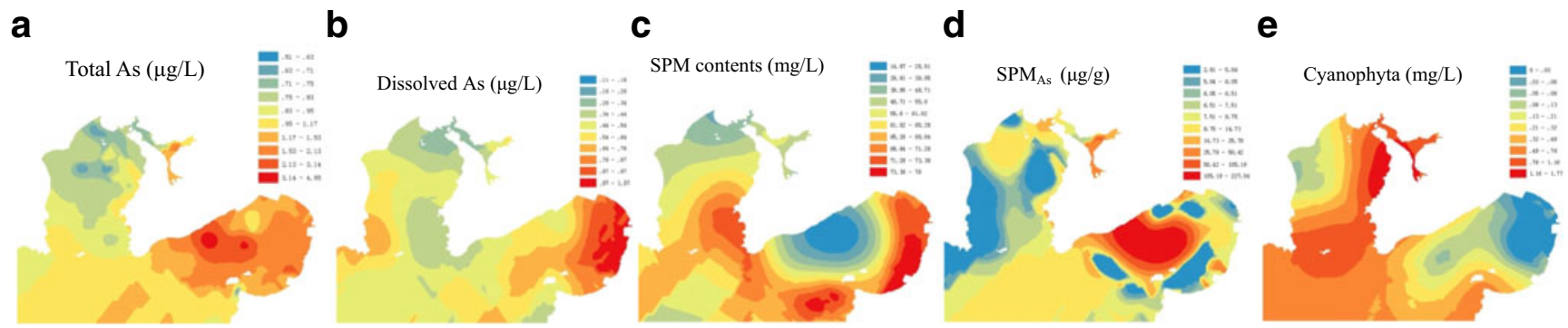

Fig. 2 Interpolation mapping in Lake Taihu in winter. a Total As $(\mu \mathrm{g} / \mathrm{L})$, b dissolved As $(\mu \mathrm{g} / \mathrm{L})$, c SPM contents $(\mathrm{mg} / \mathrm{L})$, d As concentration $(\mu \mathrm{g} / \mathrm{g})$ in $\mathrm{SPM}$, and e biomass of Cyanophyta ( $\mathrm{mg} / \mathrm{L}$ )

Taihu, DO, Chl-a, and $\mathrm{pH}$ varied in slight seasonal differences, with levels higher in winter than in summer, while the reverse was observed for $\mathrm{pH}, \mathrm{TP}$, and $\mathrm{TN}$ (Table 1).

\section{Total and dissolved As}

The total and dissolved As concentrations in the three lakes were, on average, below 6.0 and $3.3 \mu \mathrm{g} / \mathrm{L}$ (Table 1). Total As in Lake Chaohu $(5.9 \mu \mathrm{g} / \mathrm{L})$ was the highest of the three lakes, but only slightly greater than that in Dianchi. However, dissolved As in Lake Dianchi appeared to be much higher than those in the other two lakes. The concentrations of both total and dissolved As were at a minimum in Taihu in the winter (1.3 and $0.6 \mu \mathrm{g} / \mathrm{L}$, respectively).

The concentration gradients within each sampling site were interpolated to visualize the spatial variation of As in three lakes (Figs. 2, 3, 4, and 5). Total and dissolved As had similar spatial distribution patterns. Both had hot spots, decreased moving towards the southwest in Gonghu Bay and increased moving south in Meiliang Bay in Taihu in the winter (Fig. 2a, b). Arsenic concentrations throughout Taihu in the summer were quite stable, with slight fluctuations (Fig. 3a, b). The total As concentrations in the center of Chaohu were higher than those along the edge, whereas the dissolved As rapidly decreased in the east (Fig. 4a, b). For Dianchi, total and dissolved As were most highly concentrated in Caohai and decreased to the south in Waihai (Fig. 5a, b).

\section{Arsenic in SPM}

The particulate fraction was often abundant in the studied area (Table 1). The SPM concentration ranged between 14.7 and $76 \mathrm{mg} / \mathrm{L}$ and 15.6 and $97 \mathrm{mg} / \mathrm{L}$ in winter and summer in Taihu, respectively. In Chaohu and Dianchi, the concentration ranged between 1.6 and $106 \mathrm{mg} / \mathrm{L}$ and 1.0 and $81 \mathrm{mg} / \mathrm{L}$, respectively. The As absorbed in $\mathrm{SPM}\left(\mathrm{SPM}_{\mathrm{As}}\right)$ was determined by Eq. (1) using the available data. The highest mean value was observed in Dianchi $(516 \mu \mathrm{g} / \mathrm{g})$, followed by Chaohu $(216 \mu \mathrm{g} / \mathrm{g})$ and Taihu $(112 \mu \mathrm{g} / \mathrm{g}$ in summer and $25 \mu \mathrm{g} / \mathrm{g}$ in winter). The distribution of SPM concentrations and total As in SPM are shown in Figs. 2, 3, 4, and 5. In general, the spatial variation of SPM had a slightly reversed trend as compared with the As in SPM(Figs. 2c, d; 3c, d; 4c, d; and $5 \mathrm{c}, \mathrm{d})$.

\section{Phytoplankton}

In the three lakes, a total of 7 phyla and 79 species were identified: Chlorophyta (47), Bacillariophyta (18), Cyanophyta (10), 5 species belonging to Cryptophyta and Euglenophyta, and 4 other species. Cell abundances in Lake Taihu in summer were the highest, followed by Dianchi, Chaohu in summer, and Taihu in winter. Biomass concentrations decreased in the order of Dianchi, Taihu, and Chaohu (Table 2). The average biomass at each sampling site was 5.6 and $3.5 \mathrm{mg} / \mathrm{L}$ in Taihu in winter

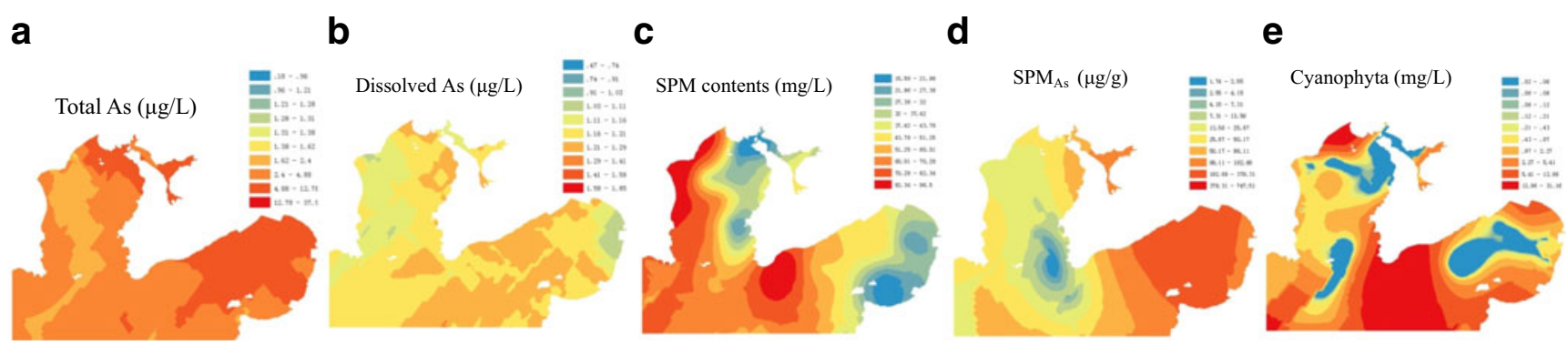

Fig. 3 Interpolation mapping in Lake Taihu in summer. a Total As $(\mu \mathrm{g} / \mathrm{L})$, b dissolved As $(\mu \mathrm{g} / \mathrm{L}), \mathbf{c} \mathrm{SPM}$ contents $(\mathrm{mg} / \mathrm{L}), \mathbf{d}$ As concentration $(\mu \mathrm{g} / \mathrm{g})$ in $\mathrm{SPM}$, and e biomass of Cyanophyta $(\mathrm{mg} / \mathrm{L})$ 

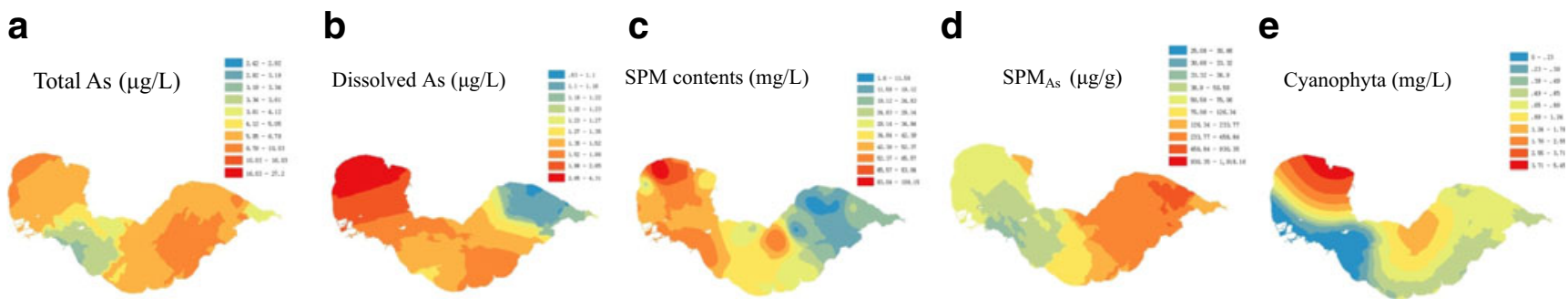

Fig. 4 Interpolation mapping in Lake Chaohu. a Total As ( $\mu \mathrm{g} / \mathrm{L}), \mathbf{b}$ dissolved As ( $\mu \mathrm{g} / \mathrm{L}), \mathbf{c}$ SPM contents $(\mathrm{mg} / \mathrm{L})$, d As concentration ( $\mu \mathrm{g} / \mathrm{g})$ in SPM, and e biomass of Cyanophyta $(\mathrm{mg} / \mathrm{L})$

and summer, respectively, while the cell abundances were $2.3 \times 10^{7}$ and $14.9 \times 10^{7}$ cells $/ \mathrm{L}$, respectively. This difference was primarily due to the intense proliferation of Bacillariophyta in the winter, since the single-cell biomass of this algae was much larger than the others.

In Taihu, the algal abundance varied greatly between two seasons, with $70.9 \%$ Cyanophyta and $22.8 \%$ Bacillariophyta in winter, while $99.6 \%$ Cyanophyta in summer. For algal biomass, Bacillariophyta was the dominant in winter, with $79.6 \%$ of the total, while Cyanophyta prevailed as $86.0 \%$ in summer. In Chaohu and Dianchi, the cell abundance patterns obtained in summer were equivalent to that in Taihu at the same season, with Cyanophyta having an absolute advantage. In Chaohu, Cyanophyta, Chlorophyta, and Bacillariophyta comprised only 30.0, 34.4 , and $23.7 \%$ of algae biomass, while the algae biomass of Dianchi was composed with $64.3 \%$ Cyanophyta and $22.1 \%$ Chlorophyta. Since Cyanophyta was the dominant phytoplankton group, and it was therefore selected to further analyze the spatial biomass distribution in the lakes (Figs. 2, 3, 4, and 5e). The distribution of Cyanophyta was consistently lower in north Meiliang Bay in Taihu, while Cyanophyta was in high spots in the northern regions of Chaohu and Dianchi.

\section{The correlation between As in water and SPM}

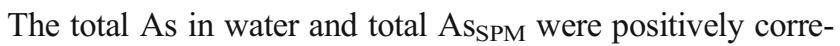
lated in all three lakes $\left(R^{2}>0.735\right)$ (Table 3), while no correlations was found between dissolved As concentrations and As in SPM $\left(\mathrm{SPM}_{\mathrm{As}}\right)$. In addition, the total As in water also demonstrated a positive relationship with As in SPM $\left(R^{2}>0.546\right)$. A strong positive correlation was found between the total and dissolved As in Dianchi $\left(R^{2}=0.852\right)$, while a weak negative correlation was observed between SPM contents and As in SPM ( $R^{2}$ between -0.208 and -0.667$)$. Cyanophyta had a positive relationship with total algae in Taihu in summer, so did in Chaohu..

\section{Discussion}

Lakes Taihu, Chaohu, and Dianchi, which are the most seriously polluted in China, covering large surface and shallow depth, bottom sediments are easily resuspended, the partitioning and behavior of As in surface water thus are most sensitive and complicated to every change in water conditions (Baeyens et al. 1998). In this work, the general water characteristics of the three lakes were similar in summer, while the total and dissolved As concentrations in the three lakes were, on average, below 6.0 and $3.3 \mu \mathrm{g} / \mathrm{L}$ (Table 1). This is consistent with the previous reports of Zhang et al. (2013), who reported that the concentration of As in water and sediments in Lake Taihu was $1.39-5.65 \mu \mathrm{g} / \mathrm{L}$ and $4.66-10.85 \mathrm{mg} / \mathrm{kg}$, while the value for Lake Dianchi was 3.08-10.48 $\mu \mathrm{g} / \mathrm{L}$ and $12.49-169.25 \mathrm{mg} / \mathrm{kg}$, respectively. It is interesting to note that high significant positive correlations found between total As in water and SPM $\left(R^{2}=0.735-1.000\right)$, but relatively weaker a

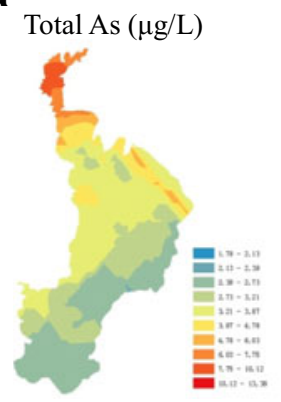

b

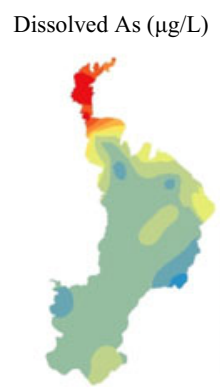

C

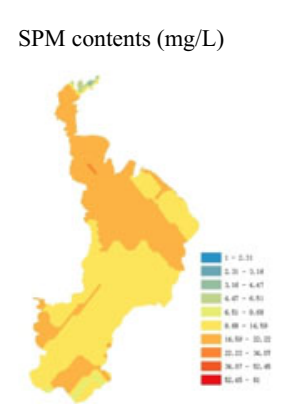

d

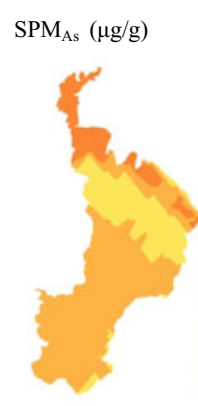

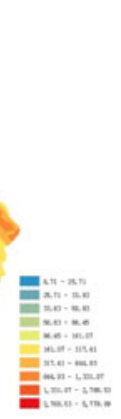

e

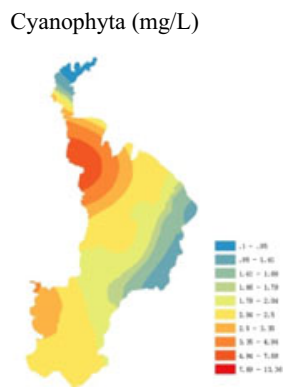

Fig. 5 Interpolation mapping in Lake Dianchi. a Total As ( $\mu \mathrm{g} / \mathrm{L})$, b dissolved As ( $\mu \mathrm{g} / \mathrm{L})$, c SPM contents (mg/L), d As concentration ( $\mu \mathrm{g} / \mathrm{g})$ in SPM, and e biomass of Cyanophyta $(\mathrm{mg} / \mathrm{L})$ 


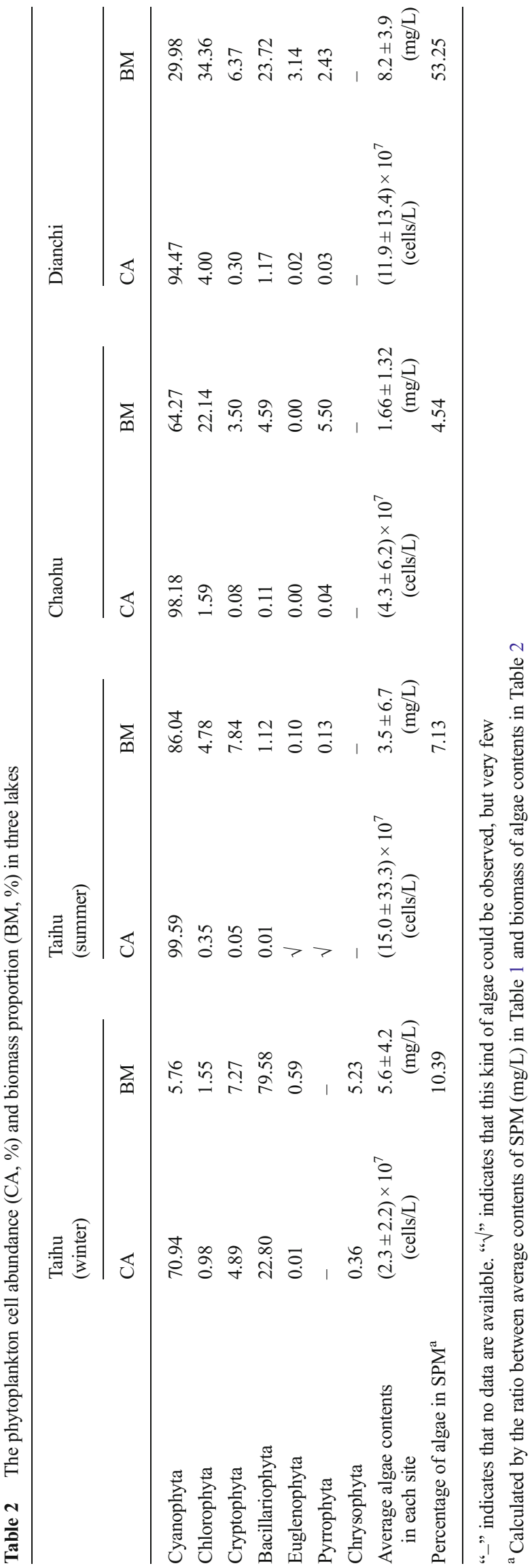

correlations existed between total As and dissolved As $\left(R^{2}=0.208-0.852\right)$. The above phenomena suggest that As might tend to be adhered more to particles when lacustrine As concentrations were high.

A significant seasonal variation was observed in the As concentrations of Lake Taihu (Table 1), where both the total and dissolved As were higher in summer than in winter. These trends in As occurrence and distribution in lake waters have also been previously reported (Hasegawa et al. 2009, 2010; Barringer et al. 2011). In the summer, As was released to the bottom water layer from sediments under anaerobic conditions. In winter, $\mathrm{Fe} / \mathrm{Mn}$ oxides can adsorb As, and the complexes settle back into the sediments (Kuhn and Sigg 1993; Hasegawa 1997; Harrington et al. 1998). However, the SPM contents and the spatial variation were similar in both seasons of Taihu (Figs. 2c and 3c). This is thought to be mediated by the prevailing north-eastern winds throughout the year, and SPM hot spots could be observed in the downwind direction of the study area.

The As in water in the three lakes were low and generally in the same order of magnitude, and SPM contents between the lakes also showed little difference, whereas As in SPM in Dianchi was much higher than those in Taihu and Chaohu. This is consistent with the much higher proportions of Algae in SPM in Dianchi than those in Taihu and Chaohu (Table 2), suggesting again biota compositions in these eutrophicated lakes played important role in As accumulation in SPM. In lake Taihu, the SPM contents were observed only in minor changes, in contrast with the fact that As in SPM in summer was much higher than that in winter. The proportion of Cyanophyta in the total algal biomass in winter (5.7\%) was much less than that in summer (86\%), which is in accordance with As in SPM (24.7 and $113 \mu \mathrm{g} / \mathrm{g}$, respectively), suggesting Cyanophyta might play vital role on As in SPM. A previous study also reported that the total suspended particulates in Dianchi were composed by $80 \%$ organic suspended matter (OSM), being primarily biota in lake Dianchi (Shi et al. 2010). The positive correlations between biomass of Cyanophyta with As in SPM in summer Taihu and Chaohu further enhance this idea (Table 3).

TLI, an index for assessing eutrophication through chlorophyll, TN, and TP, was calculated for Taihu and Chaohu using the equation of OECD (OECD 1982). The average TLI values in Taihu and Chaohu were 122 and 120, respectively, which is greater than 70, the threshold for hypertrophic status in a lake (Wang et al. 2002). Only total P was available in Dianchi, and therefore, a single factor-based index with total $\mathrm{P}$, which also indicated a hypertrophic status. Martin and Pedersen (2002) also found that eutrophication resulted in As increases in lakes; this is consistent with our results. During an algal bloom, $\mathrm{P}^{\mathrm{V}}$ may be in short supply, and phytoplankton may actively absorb $\mathrm{As}^{\mathrm{V}}$ 
Table 3 Correlation analysis of arsenic in water and SPM with biomass of Cyanophyta and total algae in three lakes (Taihu in two seasons as summer and winter, Chaohu and Dianchi in one season as summer)

\begin{tabular}{|c|c|c|c|c|c|c|c|}
\hline & $\begin{array}{l}\text { Total } \\
\text { As }\end{array}$ & $\begin{array}{l}\text { Dissolved } \\
\text { As }\end{array}$ & $\begin{array}{l}\text { Total } \\
\text { As }_{\text {SPM }}\end{array}$ & SPM & $\mathrm{SPM}_{\mathrm{As}}$ & Cyanophyta & $\begin{array}{l}\text { Total } \\
\text { algae }\end{array}$ \\
\hline \multicolumn{8}{|l|}{ Taihu, winter } \\
\hline Total As & 1.000 & & & & & & \\
\hline $\begin{array}{l}\text { Dissolved } \\
\text { As }\end{array}$ & $0.410^{*}$ & 1.000 & & & & & \\
\hline Total AssPM & $0.948 * *$ & 0.121 & 1.000 & & & & \\
\hline SPM & $-0.427^{*}$ & 0.204 & $-0.545^{* *}$ & 1.000 & & & \\
\hline $\mathrm{SPM}_{\mathrm{As}}$ & $0.905^{* *}$ & 0.075 & $0.964 * *$ & $-0.667^{* *}$ & 1.000 & & \\
\hline Cyanophyta & -0.333 & $-0.393 *$ & -0.225 & 0.161 & -0.187 & 1.000 & \\
\hline Total algae & -0.103 & -0.217 & -0.034 & 0.143 & -0.047 & -0.037 & 1.000 \\
\hline \multicolumn{8}{|c|}{ Taihu, summer } \\
\hline Total As & 1.000 & & & & & & \\
\hline $\begin{array}{l}\text { Dissolved } \\
\text { As }\end{array}$ & $0.387^{*}$ & 1.000 & & & & & \\
\hline Total AssPM & $1.000 * *$ & $0.431^{*}$ & 1.000 & & & & \\
\hline SPM & -0.054 & -0.054 & 0.130 & 1.000 & & & \\
\hline $\mathrm{SPM}_{\mathrm{As}}$ & $0.972 * *$ & $0.446^{*}$ & $0.971 * *$ & -0.208 & 1.000 & & \\
\hline Cyanophyta & -0.134 & -0.022 & -0.183 & $0.369^{*}$ & -0.174 & 1.000 & \\
\hline Total algae & -0.153 & -0.058 & -0.205 & $0.375^{*}$ & -0.200 & $0.996^{* *}$ & 1.000 \\
\hline \multicolumn{8}{|l|}{ Chaohu } \\
\hline Total As & 1.000 & & & & & & \\
\hline $\begin{array}{l}\text { Dissolved } \\
\text { As }\end{array}$ & 0.208 & 1.000 & & & & & \\
\hline Total AssPM & $0.991 * *$ & 0.078 & 1.000 & & & & \\
\hline SPM & 0.156 & $0.676^{* *}$ & 0.069 & 1.000 & & & \\
\hline $\mathrm{SPM}_{\mathrm{As}}$ & $0.546^{* *}$ & -0.285 & $0.594 * *$ & $-0.436^{* *}$ & 1.000 & & \\
\hline Cyanophyta & 0.115 & $0.526^{* *}$ & 0.048 & $0.424 * *$ & -0.118 & 1.000 & \\
\hline Total algae & 0.027 & $0.410 * *$ & -0.027 & 0.310 & -0.081 & $0.965^{* *}$ & 1.000 \\
\hline \multicolumn{8}{|l|}{ Dianchi } \\
\hline Total As & 1.000 & & & & & & \\
\hline $\begin{array}{l}\text { Dissolved } \\
\text { As }\end{array}$ & $0.852 * *$ & 1.000 & & & & & \\
\hline Total As $\mathrm{APM}_{\mathrm{SPM}}$ & $0.735^{* *}$ & 0.338 & 1.000 & & & & \\
\hline SPM & 0.068 & -0.011 & 0.086 & 1.000 & & & \\
\hline $\mathrm{SPM}_{\mathrm{As}}$ & $0.655^{* *}$ & 0.420 & $0.718 * *$ & -0.292 & 1.000 & & \\
\hline Cyanophyta & -0.229 & -0.234 & -0.217 & 0.127 & -0.250 & 1.000 & \\
\hline Total algae & $0.440^{*}$ & $0.570 * *$ & 0.079 & 0.386 & -0.085 & $0.459^{*}$ & 1.000 \\
\hline
\end{tabular}

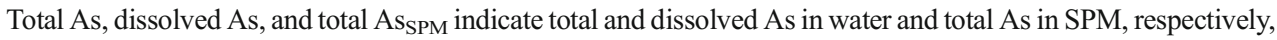
while SPM represents the contents of SPM in water and $\mathrm{SPM}_{\mathrm{As}}$ represents As adhered in SPM. Total As $\mathrm{SPM}_{\mathrm{SP}}$ was the reduction of total and dissolved As in waters, while $\mathrm{SPM}_{\mathrm{As}}$ was calculated by $\mathrm{SPM}_{\mathrm{As}}=$ Total $\mathrm{As}_{\mathrm{SPM}} / \mathrm{SPM}$

Correlation is significant at the $* P<0.05$ level and $* * P<0.01$ level in its place because of the similarities between $\mathrm{As}^{\mathrm{V}}$ and $\mathrm{PO}_{4}{ }^{3-}$ (Hellweger and Lall 2004). The adsorption of dissolved As onto particulate phases has been widely studied, and most of the reports claimed that inorganic iron oxides and hydroxides in SPM had high adsorptive capabilities (Sharma and Sohn 2009). However, in the present study, the much higher biota compositions in the SPM in the three lakes with hypertrophic status of eutrophication might probably undermine such capabilities.
The partition coefficient, defined as $\mathrm{Kd}(\mathrm{mL} / \mathrm{g})=$ As sorbed in SPM $(\mu \mathrm{g} / \mathrm{g}) /$ dissolved As in waters $(\mathrm{mg} / \mathrm{L})$, can provide empirical information on the combined effects of heterogeneous reactions such as adsorption, desorption, and precipitation (Turner 1996). The Kd values (As) in the present study $\left(43-157 \times 10^{3} \mathrm{~mL} / \mathrm{g}\right)$ were much higher than most Kd values in freshwaters from the literature (e.g., East-Hainan estuaries (China) $30-65 \times 10^{3} \mathrm{~mL} / \mathrm{g}$ (Balzer et al. 2013); Gironde estuary (France) $5-11 \times 10^{3} \mathrm{~mL} / \mathrm{g}$ (Masson et al. 2009); Humber Plume 
(England) $2-25 \times 10^{3} \mathrm{~mL} / \mathrm{g}$ (Millward et al. 1997)). The main differences to these $\mathrm{Kd}$ values might be due to many reasons, such as the higher SPM contents, and the lower concentration of organic matter in the SPM in literature reports than this study (Balzer et al. 2013), etc. More information on As in phytoplankton and other fractions in SPM in the eutrophicated lakes is needed to clarify the exact role of biota on the partitioning of As between the aqueous and particulate phases.

\section{Conclusions}

The total and dissolved As in water as well as SPM contents in the three large shallow lakes in China, e.g., Taihu, Chaohu, and Dianchi, were generally low and in the same magnitude order, while As in SPM differed greatly, with that in Dianchi being much higher than those in Taihu and Chaohu, consistent with the much higher proportions of biota in Dianchi than those in the other two lakes. Arsenic tented to be adhered to SPM, largely due to the hypertrophic status in eutrophication of the three lakes. Phytoplankton in these lakes can take up As in addition to phosphate; this biological activity can be intensified by eutrophication, producing significant effect on As cycling in the aquatic systems. SPM in these large shallow hypertrophic state freshwater lakes are quite complex in composition, with large contribution of biota, the role of this biota on As partitioning between aqueous and particulate phases was seen in this study; however, the exact roles of various inorganic and organic compositions in the SPM on As adsorption-desorption are needed to be clarified in future studies.

Acknowledgments We thank Mr. Nan Zhang, Mr. Kai Fan, and Mr. Xiaodong Zhu for their assistance in the sample collection and the staff at the workstations at Lakes Taihu, Chaohu, and Dianchi during the field survey. We also thank Prof. Guangwei Zhu and Dr. Xue from the Nanjing Institute of Geography and Limnology, Chinese Academy of Sciences, for their kind assistance in the field survey. This study was financially supported by the National Natural Science Foundation of China (Grant No. 41271477).

\section{References}

Baeyens W, Elskens M, Gillain G et al (1998) Biogeochemical behaviour of $\mathrm{Cd}, \mathrm{Cu}, \mathrm{Pb}$ and $\mathrm{Zn}$ in the Scheldt estuary during the period 1981 1983. Hydrobiologia 366:15-44

Balzer W, Boehler E, Tang XL et al (2013) Arsenic in solution, colloidal and particulate phases of East-Hainan estuaries. Cont Shelf Res 57: $73-81$

Barringer JL, Bonin JL, Deluca MJ et al (2007) Sources and temporal dynamics of arsenic in a New Jersey watershed, USA. Sci Total Environ 379:56-74

Barringer JL, Szabo Z, Wilson TP et al (2011) Distribution and seasonal dynamics of arsenic in a shallow lake in northwestern New Jersey, USA. Environ Geochem Health 33:1-22
Du L, Li Y, Chen X et al (2011) Effect of eutrophication on molluscan community composition in the Lake Dianchi (China, Yunnan). Limnologica - Ecol Manag Inland Waters 41:213-219

Ebina J, Tsutsui T, Shirai T (1983) Simultaneous determination of total nitrogen and total phosphorus in water using peroxodisulfate oxidation. Water Res 17(12):1721-1726

Geng D, Yang F, Wei CY et al. (2015) Effects of wind-wave disturbance on the partition of arsenic between the water-suspended solids phase of Lake Taihu. Acta Scientiae Circumstantiae 05:1358-1365

Harrington JM, Fendorf SE, Rosenzweig RF (1998) Biotic generation of arsenic(III) in metal(loid) contaminated freshwater lake sediments. Environ Sci Technol 32:2425-2430

Hasegawa H (1997) The behavior of trivalent and pentavalent methylarsenicals in Lake Biwa. Appl Organomet Chem 11:305-311

Hasegawa H, Rahman MA, Matsuda T et al (2009) Effect of eutrophication on the distribution of arsenic species in eutrophic and mesotrophic lakes. Sci Total Environ 407:1418-25

Hasegawa H, Rahman MA, Kitahara K et al (2010) Seasonal changes of arsenic speciation in lake waters in relation to eutrophication. Sci Total Environ 408:1684-90

Hellweger FL, Lall U (2004) Modeling the effect of algal dynamics on arsenic speciation in Lake Biwa. Environ Sci Technol 38:67166723

Hu H, Wei Y (2006) The freshwater algae of China - systematics, taxonomy and ecology. Science Press, Beijing

$\mathrm{Hu} \mathrm{L}, \mathrm{Hu}$ W, Zhai S et al (2010) Effects on water quality following water transfer in Lake Taihu, China. Ecol Eng 36:471-481

Huo W, Chen J (1997) Water-particulate distribution coefficient of heavy metal and application in sediment quality criteria in China river. Chin J Environ Sci 7:10-14

Kar S, Das S, Jean JS, Chakraborty S et al (2013) Arsenic in the watersoil-plant system and the potential health risks in the coastal part of Chianan Plain, Southwestern Taiwan. J Asian Earth Sci 77:295-302

Kuhn A, Sigg L (1993) Arsenic cycling in eutrophic Lake Greifen, Switzerland: influence of seasonal redox processes. Limnol Oceanogr 38:1052-1059

Linge KL, Oldham CE (2002) Arsenic remobilization in a shallow lake: the role of sediment resuspension. J Environ Qual 31:822-828

Mandal BK, Suzuki KT (2002) Arsenic round the world: a review. Talanta 58:201-235

Martin AJ, Pedersen TF (2002) Seasonal and interannual mobility of arsenic in a lake impacted by metal mining. Environ Sci Technol 36:1516-1523

Masson M, Schäfer J, Blanc G et al (2009) Behavior of arsenic and antimony in the surface freshwater reaches of a highly turbid estuary, the Gironde Estuary, France. Appl Geochem 24:1747-1756

Millward GE, Kitts HJ, Ebdon L et al (1997) Arsenic species in the Humber Plume, UK. Cont Shelf Res 17:435-454

Nguyen HL, Leermakers M, Elskens M et al (2005) Correlations, partitioning and bioaccumulation of heavy metals between different compartments of Lake Balaton. Sci Total Environ 341:211-226

Nikolaidis NP, Dobbs GM, Chen J et al (2004) Arsenic mobility in contaminated lake sediments. Environ Pollut 129:479-487

OECD (1982) Eutrophication of waters. Monitoring, assessment and control.

Pertsemli E, Voutsa D (2007) Distribution of heavy metals in Lakes Doirani and Kerkini, Northern Greece. J Hazard Mater 148:529-537

Rahman MA, Hasegawa H (2012) Arsenic in freshwater systems: influence of eutrophication on occurrence, distribution, speciation, and bioaccumulation. Appl Geochem 27:304-314

Sharma VK, Sohn M (2009) Aquatic arsenic: toxicity, speciation, transformations, and remediation. Environ Int 35:743-759

Shi K, Li Y, Zhu L et al (2010) Parameterization of a scattering coefficient model for Dianchi Lake, China. Acta Sci Circumst 30:1479-1485 
Smedley PL, Kinniburgh DG (2002) A review of the source, behaviour and distribution of arsenic in natural waters. Appl Geochem 17:517568

Sohrin Y, Matsui M, Kawashima M et al (1997) Arsenic biogeochemistry affected by eutrophication in Lake Biwa. Japan Environ Sci Technol 31:2712-2720

Takamatsu T, Kawashima M, Koyama M (1985) The role of Mn2+-rich hydrous manganese oxide in the accumulation of arsenic in lake sediments. Water Res 19:1029-1032

Tang W, Shan B, Zhang H et al (2010) Heavy metal sources and associated risk in response to agricultural intensification in the estuarine sediments of Chaohu Lake Valley, East China. J Hazard Mater 176: 945-951

Turner A (1996) Trace-metal partitioning in estuaries: importance of salinity and particles concentration. Mar Chem 54:27-39

Wang M, Liu X, Zhang J (2002) Evaluate method and classification standard on lake eutrophication. Environmental Monitoring in China 05:47-49.
Wang C, Shen C, Wang PF et al (2013) Modeling of sediment and heavy metal transport in Taihu Lake, China. J Hydrodynamics Ser B 25: 379-387

Zhang J, Wang Z, Song Z et al (2012) Bioaccumulation of microcystins in two freshwater gastropods from a cyanobacteria-bloom plateau lake, Lake Dianchi. Environ Pollut 164:227-234

Zhang N, Wei CY, Yang LS (2013) Occurrence of arsenic in two large shallow freshwater lakes in China and a comparison to other lakes around the world. Microchem J 110:169-177

Zhang X, Chen Q, Recknagel F et al (2014) Wavelet analysis of time-lags in the response of cyanobacteria growth to water quality conditions in Lake Taihu, China. Ecol Inf 22:52-57

Zheng S, Wang P, Wang C et al (2013) Distribution of metals in water and suspended particulate matter during the resuspension processes in Taihu Lake sediment, China. Quat Int 286:94-102 